\title{
Work and Employment for the Heritage: System Analysis of an Economic Asset for an Innovative Welfare Model
}

\author{
By Ivan Drogo Inglese* \& Roberta Caragnano ${ }^{ \pm}$
}

\begin{abstract}
In this essay, which starts from the current scenario triggered by the COVID-19 pandemic and from the impact it has had on various sectors, the Authors lay the foundations for the study of a welfare of the heritage to accompany the cultural welfare through the creation of a model of integrated management of the same (heritage) both in aspects related to the enhancement and in those inherent in the process of cultural innovation, aiming attention at an international audience. A welfare that bets on the creation of "ecosystems" of welfare of the heritage able to connect to European clusters for a participatory management of the same, in the renewed scenario of economic recovery where the combination of culture and employment is central. All is analysed and contextualised in the welfare dimension/view. This essay, according to a definitive methodological approach in the opening paragraphs, reviews the value of culture and heritage in the European scenario - including a focus on the National Recovery and Resilience Plan - along with the themes of sustainable development and cultural indicators 2030, passing through the analysis of cultural activators and circular business models. In the second part, the effects of the pandemic on cultural employment are analysed, as well as scenarios of new professionalism in the job market in the sectors of heritage and culture, without neglecting the focus on the relationship between tourism and culture. According to a circular path, which is connected to the incipit of the essay that at the beginning refers to the Assembly of "Gli Stati Generali del Patrimonio Italiano" (The General States of the Italian Heritage), the Authors outline the perspectives de iure condendo also related to the workshop activities of the Assembly and to the need to iitiate among stakeholders (public and private) a continuous and participatory confrontation in order to promote, on the one hand, a new and sustainabe entrepreneurship of cultural heritage, and on the other hand, structural policies aimed at creating employment.
\end{abstract}

Keywords: Cultural heritage; Welfare; Employment; Economic asset.

\footnotetext{
"President of "Gli Stati Generali del Patrimonio Italiano"/“The General States of the Italian Heritage"; President of Assopatrimonio and Assocastelli.

Email: segreteria@statigeneralipatrimonio.it

${ }^{ \pm}$Professor of Law of Social Policies and Labour - LUMSA University, Rome, Italy; General Secretary of "Gli Stati Generali del Patrimonio Italiano"/“The General States of the Italian Heritage”. Email: caragnano.roberta@gmail.com
} 


\section{Introduction}

This essay is inscribed in the current economic, regulatory and sociological framework and, starting from the effects of the pandemic crisis (triggered by COVID-19) and the new needs of the population, it carefully looks at the health and well-being prism, its different facets and the centrality of culture and heritage as economic assets. Everything is analysed and contextualised in the dimension of wellness. The concept of wellness, therefore, is enriched with content, becoming a broad category that goes beyond the mere measurement of income, and that represents a dimension of individuals', States' and society's health in general, and businesses in line with the most advanced experiences, including those overseas ${ }^{2}$, which propose a «shift of emphasis from the measurement of economic production to the measurement of people's well-being ${ }^{3} »$.

It is in this scenario that cultural welfare that generates wellness arises, as noted by the World Health Organization (hereinafter - WHO) in the 2019 research, What is the evidence on the role of the arts in improving health and well-being? ${ }^{4}$. In this case, according to the $\mathrm{WHO}^{5}$, cultural welfare, meant as the ability of cultural experiences to influence the behavior of individuals, has positive effects on the same (individuals) both for the prevention of diseases (such as autism spectrum disorders, cardiovascular disease, Parkinson's disease) and for health promotion, treatment and management of certain diseases that may occur throughout life. In practice, therefore, artistic-cultural activities have healthy effects on both mental and physical health, and they are also evaluated with economic indicators.

In the vision of the authors of this essay, "heritage welfare" flanks cultural welfare and enriches it in a new and broader vision, which is not only a support to social welfare services - in order to guarantee assistance for fragile categories (elderly and disabled) as in the traditional concept (of cultural welfare) sustained by Pier Luigi Sacco ${ }^{6}$ - but which is projected into a new meaning of culture and heritage (both material and immaterial) as an element and "domain" that - to use the terminology and declination of the ESW Report (Equal and Sustainable Wellbeing) - aims at well-being.

The aim of this essay is, therefore, twofold: on the one hand, to lay the foundations for an innovative line of research, namely the one of the welfare of heritage according to the above-mentioned definition, and on the other hand, to activate internships that, through the creation of a model of integrated management

\footnotetext{
${ }^{2}$ In the Report, How are Canadians really doing? Canadian Index of Wellbeing, October 2012, in which the impact of crises on the quality of life of individuals is examined, the conclusion is reached, in light of the data, that there is a need to promote a better quality of life and to that end public policies must have a significant impact on well-being.

${ }^{3}$ Stiglitz, Sen, Fitoussi (2009).

${ }^{4}$ OMS (2019).

${ }^{5}$ In the above-mentioned research, The WHO has mapped, in an interdisciplinary manner, over 3,000 studies in the last 20 years between English and Russian academic literature and analysed the link between the arts and health.

${ }^{6}$ Sacco (2017).
} 
of the same (heritage) both in aspects related to the enhancement and in those inherent in the process of cultural innovation, aim to catch the attention of an international audience.

In this renewed concept, "Gli Stati Generali del Patrimonio Italiano" (The General States of the Italian Heritage), an initiative of Assopatrimonio ${ }^{7}$, with the support of public and private Institutions, Universities, Foundations and other stakeholders, aims to analyse the state of the art of our heritage, and also to initiate a survey and concretise actions and proposals, contributing to the definition of welfare of the heritage that generates wealth, employment and work for younger generations and local communities.

\section{Findings/Results}

Problem Definition and Methodological Approach: The Basis for a New Welfare Model

The health crisis caused by Covid-19 has led to an economic "contagion" (resulting from the non-self-sufficiency of Countries and Companies in an increasingly globalised context) that, with a domino effect, has overwhelmed the economies of States.

In September 2019, in the Report A world at risk, Annual report on global preparedness for health emergencies Global Preparedness Monitoring Board ${ }^{8}$, the result of a joint study by the World Bank and the World Health Organization, estimated - in a first ideal comparison - an economic effect, in the event of a pandemic, with a fluctuation ranging between 2.2 and 4.8 percent of GDP.

In 2018, a study by Victoria Fan $^{9}$ et al. highlighted the economic cost of a possible pandemic and estimated at «up to $\$ 500$ billion per year (i.e., 0.6 percent of world income) the total value of the losses of an extended pandemic influenza, including not only the direct costs due to increased mortality and disruption of operations in many sectors, but also the lost income due to the subsequent reduction in the size of the labor force and productivity, as well as reduced demand due to restrictions on the mobility of people ${ }^{10} \gg$. As noted also by Italian scholars, «this is a much greater impact than that of Sars, which affected economically mainly China and Hong Kong ( -3 and -4.75 percent of GDP respectively in the second quarter after the epidemic), with lesser effects only in Canada and Singapore, and in any case limited to a single quarter (Marcus KeoghBrown and Richard Smith 2008) ${ }^{11} \gg$.

\footnotetext{
7"'Gli Stati Generali del Patrimonio Italiano" is an initiative promoted by Assopatrimonio, under the patronage of CNEL (Consiglio Nazionale dell'Economia e del Lavoro / National Council of Economy and Work). The first Assembly was held in Rome on May 20, 2021, at the Villa Lubin venue.

${ }^{8}$ GPMB (2019). See the following link: http://apps.who.int/gpmb/assets/annual_report/GPMB annu alreport_2019.pdf.

${ }^{9}$ Fan, Jamison \& Summers (2018).

${ }^{10}$ Amighini (2020).

${ }^{11}$ Amighini (2020).
} 
Forecasts, to name but a few, that for several years had been enriching the economic literature fearing a risk that was much closer than previously thought.

However, it was inevitable that the pandemic would have a strong backlash on employment. In the latest ILO note Covid-19 and the world of work: $7^{\text {th }}$ edition of January 25, 2021, the massive impact on job markets in 2020 is confirmed, bringing with it not only a decrease in work hours but also a worrisome increase in inactivity relative to unemployment. According to the latest estimates in the year 2020, 8.8 percent of hours worked globally were lost compared to the fourth quarter of the previous year (i.e. 2019) with a corresponding loss of 255 million full-time jobs; overall, according to the data still, the losses in worked hours were about four times greater than during the 2009 financial crisis.

The result is the change in the global scenario caused by the pandemic, with effects on the global job market and employment as well as on the policies implemented by international and community Institutions, States and local welfare systems. The latter have had to deal with the emergency by adapting - and redefining in the course of the work - their own structures in order to meet the needs and requirements of families and workers, given the complexity of the phenomenon which is increasingly multidimensional and complex in nature.

A shock that for many Countries, including Italy, has made it necessary to initiate, or accelerate, processes aimed at remodeling and redefining the system of social policies with the provision of actions and tools capable of offering personalised services based on the different needs and requirements of the population in order to overcome the traditional concept of social welfare.

In this sense, and from a sociological point of view, the dualistic State-Market model, and in particular the Mediterranean welfare model, which has already been in crisis for years, has seen its course accelerated in a progressive shift from welfare state to welfare mix where the redefinition of the role of the public subject is central. Ascoli, in this regard, argues that the future of welfare models should tend to the search for paths and tools that can cope with the new problems related to overcoming the dualism state/market because in a perspective of welfare mix or welfare society «it is necessary to go towards forms of "co-planning" and "coassessment" of social interventions on the territory in which the different actors (public and third sector) are able to build networks of social protection and promotion of welfare otherwise inconceivable ${ }^{12} \gg$.

The post-covid challenge passes through a renewal of welfare in the direction of a community and cultural welfare ${ }^{13}$ but also of a "welfare of the heritage", as clarified in the Introduction to this essay.

\footnotetext{
${ }^{12}$ Ascoli \& Pasquinelli (1993); Costa (2009).

${ }^{13}$ Caragnano (2021). During the first phase of the emergency, the Cariplo Foundation and LombardiaSociale.it - which launched a study on, The future of community welfare projects, supported through the Welfare In Action program - highlighted the need for a community approach to welfare that is both generative and constantly evolving. If, on the one hand, the pandemic crisis has "distanced" people to protect themselves from contagion, on the other hand it has strengthened the sense of community identity, activating the network of volunteers, cooperatives, consortia, associations, the Third Sector, but also informal groups of citizens, who, as a result of the problem
} 
To enter into the merits of the quaestio, cultural welfare is meant, in the common meaning, «a new integrated model of promotion of welfare and health of individuals and communities, through practices based on visual arts, performing arts and cultural heritage ${ }^{14} \gg$ and that rests its roots on the recognition, also reiterated by the WHO (on the point see $\S 1$ ), the effectiveness of specific cultural, artistic and creative activities on the health of individuals.

This welfare model is based on a salutogenic approach - according to Aaron Antonovsky's theory ${ }^{15}$ - whereby it is much more important to pay attention to resources and people's ability to "create health" rather than focusing on diseases and risks. Hence the development, over the years, of a series of cultural policies that presume a systemic relationship between the institutional systems of health, social policies and those of arts and culture, as shown by European experiences, such as the one of the United Kingdom ${ }^{16}$, but also Italian, if we think of the case of the Autonomous Province of Bolzano.

The pandemic crisis, as emerges from the cited WHO Report, «brings into play social cohesion, the biopsychosocial health of communities in a profound sense and it is urgent to work on a new idea of welfare in which the Arts and Culture can make a significant contribution to the recovery of the Country. Involving public and private actors and stakeholders, working in a multidisciplinary, multi-level and cross-sector perspective, to ensure social impact and nurture policies ${ }^{17} \gg$.

From here the need and opportunity to think about new models of integrated and holistic welfare through the creation of a lab project / internship to meet the world of culture, art, heritage, professions and investments that also do not neglect cultural performance in the context of urban regeneration processes as well as the redesign and management of spaces for youth resocialization; all considering heritage as something that generates employment.

This is a facet of welfare that exceeds even the traditional vision of cultural welfare and that arises, precisely in the direction of the creation of "ecosystems" of Welfare of heritage that can connect to European clusters to activate a participatory management of heritage, in the renewed scenario that looks to economic recovery and where the combination of culture and employment is central.

A new current of welfare (of the heritage, precisely) that is in the furrow of nesting between the first and second welfare ${ }^{18}$ in which the changes taking place are not framed by the traditional categories and for which «it is necessary to pay

of home isolation for COVID, have made themselves available for the distribution of basic necessities.

${ }^{14}$ See Cicerchia, Rossi Ghiglione \& Seia (2020).

${ }^{15}$ Antonovsky (1979); Lindström \& Eriksson (2005).

${ }^{16}$ Bungay \& Clift (2010); Mental Health Foundation (2009) The United Kingdom with its Arts on prescriptive (AoP) program represents one of the most significant experiences.

${ }^{17}$ Thus, in Quali sono le evidenze sul ruolo delle arti nel miglioramento della salute e del benessere? Una scoping review, Italian language publication of the WHO report (2019). Italian translation by CCW-Cultural Welfare Center in collaboration with DORS Regione PiemonteRegional Documentation Center for Health Promotion, Medicina a Misura di Donna Foundation, SCT Centre - Social Community Theatre Centre.

${ }^{18}$ Maino (2015) at 33-34. 
attention and promote a second intertwining, so to speak lateral, between the second welfare and the environmental and socio-cultural dimensions. To which it is more than likely that many others will have to be added in the future ${ }^{19}$ ».

The assumption is that the development of well-being, autonomy and equity passes through dimensions linked to the culture, in the broadest sense, but also from overcoming the digital divide and in a new vision of empowerment in which the places of culture also become places of welfare ${ }^{20}$. It is in this vision of cultural heritage becoming the driving force of redesign and regeneration of spaces, with impacts on local welfare by creating synergies with third sector organizations and other public, private or institutional, that stands the interesting experience of the Cultural Workshops of Catania. This project has allowed access to the architectural complex of "il Monastero dei Benedettini di San Nicolò l'Arena/the

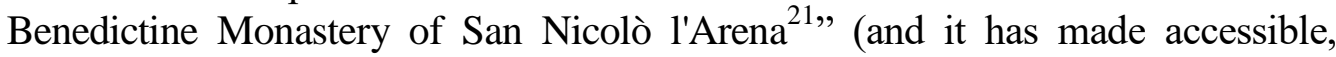
available and "understandable" to an increasing number of people the cultural heritage both for what concerns the educational and social function "involving the communities of reference in the processes of design and cultural production, as an act of awareness and participation ${ }^{22,}$.

In the context of European policies, heritage is also the object of attention in the Piano Nazionale di Ripresa e Resilienza / National Recovery and Resilience Plan (hereinafter NRRP), presented by Italy to the European Commission and which represents an instrument with which Italy intends to carry out a series of investments and strategic reforms for the use of Next Generation EU funds.

As stated in the incipit of the same (Plan), in the general aims, «Our Country has a unique heritage to protect: a natural and cultural ecosystem of inestimable value, which represents a distinctive element of present and future economic development ${ }^{23} \gg$ and in Mission 1 - which aims to give a decisive boost to the relaunch of competitiveness and productivity of the Country System - a series of actions and interventions are planned to remove architectural and sensory barriers in museums, libraries and archives, and to promote a culture of accessibility of the Italian cultural heritage. The need to enhance the cultural and touristic heritage is also highlighted in order to promote the Italy at an international level.

\footnotetext{
${ }^{19}$ See Maino \& Ferrera (2019).

${ }^{20}$ Bandera (2019); Grossi \& Ravagnan (2013); Novy (2018); Cavalli (2016).

${ }^{21}$ The complex today is home to the Department of Humanities of the University of Catania and it is a UNESCO World Heritage Site. The project shared with Officine Culturali was born from a proposal of the University, owner of the property and objectively unable to activate inclusive services of use and social communication of scientific research. Therefore, with the agreement of 2010 signed with the former Faculty of Arts and updated in 2012 directly with the University of Catania, Officine Culturali was entrusted with the enhancement of one of the most important cultural sites in Catania, namely the Benedictine Monastery.

${ }^{22}$ Mannino (2016).

${ }^{23}$ Thus in the Presidency of the Council of Ministers, National Plan for Recovery and Resi. \#NEXTGENERATIOITALIA. Italia Domani, at 20.
} 


\section{Discussion}

\section{Sustainable Heritage Development and 2030 Cultural Indicators}

The need for policies aimed at sustainable development for the protection and promotion of cultural heritage is one of the themes at the heart of the 2030 Agenda for Sustainable Development, the action program for people, prosperity and the planet signed in September 2015 by the Governments of the 193 UN member Countries, which incorporates 17 Sustainable Development Goals (SDGs) within a broader program of action for a total of 169 targets or goals.

In Goal 11, Making cities and human settlements inclusive, safe, resilient and sustainable, Target 11.4 envisages, in fact, strengthening efforts to protect and safeguard the world's cultural and natural heritage. Sustainability that is also linked to tourism (which is also sustainable) for a rediscovery of heritage, according to a broad vision that also aims to promote integrated policies for dignified work and lasting economic growth and full and productive employment. All through the use of development indicators that can bring together the objectives of the 2030 Agenda and actions already implemented. In this regard, it is worth noting, for example, the Culture for Development Indicators (CDIs) as tools for measuring the contribution of culture to development processes, the start of which was in the 2005 UNESCO Convention for the Protection and Promotion of the Diversity of Cultural Expressions ${ }^{24}$ and which considers culture as a fundamental element for sustainability.

In detail, the document shows that «Each indicator is calculated through a complex analysis. For example, the indicator "Sustainability of the Heritage" is divided into 46 items, which can be joined to 3 key components:

- Existence and development of national and international registries and related enrollments;

- Activities aimed at heritage protection, conservation, preservation and management, in tune with actions for stakeholder engagement and sustainability of assets;

- Strategies adopted to raise awareness and build support for heritage preservation and revitalization.

From the three identified areas, we can see the importance given to the relationship between heritage and society, no longer relegated to a secondary need but considered of equal importance to physical conservation. This link with society is also expressed in the protection of knowledge and traditional crafts, cultural and economic resources at the same time to the attention of objectives 8 and 12 [SDGs objectives], also devoted to the promotion of culture and local products through sustainable public policies that generate employment ${ }^{25}$. Likewise, the most recent

\footnotetext{
${ }^{24}$ Approved on October 20, 2005 by the XXIII General Conference of UNESCO. Ratified by Italy on February 19, 2007 with Law n. 19. Entered into force upon the 40th ratification, March 18, 2007.

${ }^{25}$ Avanza (2016).
} 
UNESCO report, "Culture 2030 Indicators" $(\mathrm{CI})^{26}$ of 2019, in which thematic indicators are illustrated with the aim of measuring and monitoring the contribution of culture to sustainable development.

If, on the one hand culture indeed represents a separate sector in its own, on the other hand, there is no denying its transversal nature with respect to the objectives of the 2030 Agenda and, therefore, its ability to penetrate local development plans, to facilitate processes, and to intervene in development policies to provide a methodological and analytical approach, both for the enhancement of existing sectors and for future planning. On this point, the Report specifies that the goal /target of the Cultural Indicators is to «propose evidencebased approaches with the aim of providing tools and guidelines for interpreting the cultural phenomenon as an element of great value in addressing global challenges - from climate change to increased employment, social inclusion, etc. and in ensuring the well-being of communities».

In the Report, related to each indicator there is a technical sheet in which the sources for obtaining data and instructions of a method for constructing the indicator itself are also indicated; for the quantitative indicator "Cultural employment", which is of interest for the themes dealt with in this paper, for example, UNESCO provides the formula for calculation based on the methodology adopted by the UNESCO Statistical Institute (UIS), while for the qualitative indicator "Governance of culture", UNESCO proposes a checklist through which to monitor aspects such as the presence of ministries or statistical offices responsible for collecting data on culture, often with reference to what is established by UNESCO Conventions ${ }^{27}$.

Indeed, the four cross-cutting dimensions of culture, which rework / revise the 17 goals and indicators of economic development of the 2030 Agenda, can be summarised as follows

1) Environment \& Resilience» (with reference to SDGs 2, 6, 9, 11, 12, 13, 14, 15 and 16) highlights the role of Culture for environmentally sustainable development;

2) Prosperity \& Livelihood» (SDGs 8, 10 and 11) questions the role in strategies aimed at inclusion/integration of goods and services, work, participation and communities;

3) Knowledge \& Skills (SDGs 4, 8, 9, 12, 13) focuses on the importance of soft and hard skills that exist or need to be enhanced in the cultural sector in order to trigger, facilitate and develop processes of empowerment and capacity building;

4) Inclusion \& Participation» (SDGs 9, 10, 11, 16) focuses on the possibilities for people to participate in cultural life. This last dimension

\footnotetext{
${ }^{26}$ The Report is available at https://unesdoc.unesco.org/ark:/48223/pf0000371562. See also United Nations Organization (2005); UNESCO (2019); UNESCO (2014); UNESCO (2009).

${ }^{27}$ Montalto (2021).
} 
also explores the ways in which cultural practices convey values that promote social inclusion $^{28}$.

With regard to the goals of the aforementioned Agenda 2030 Jasper Visser $^{29}$ developed, in 2018, a study in which he highlighted the actions (and related targets) put in place by museums to achieve the Sustainable Development Indicators.

From this study more than fifty targets emerged that museums can invest in to achieve their sustainability goals. Each target was identified on the basis of a number of indicators: green indicates areas in which museums are almost "pathfinders", meaning that they are working towards the achievement of sustainability goals; blue indicates targets that require the collaboration of an external body in order to achieve the goals; and red indicates targets for which internal change is necessary (in order to achieve the goals).

From this reading, therefore, it's pointed out how necessary and fundamental it is that both cultural attractions and cultural organizations take on an active and proactive role both for sustainable development and for the achievement of objectives, also in the awareness of their strategic role for local communities and society as a whole.

On this basis, the binomial culture and sustainable development begins to assert itself in the Italian legal doctrine ${ }^{30}$ as the fourth/ IV pillar of sustainable development together with the environment, economic development and social solidarity, in a vision that allows to look at the protection of heritage and the economic-legal aspects in an integrated way.

\section{Circular Economy: Cultural Activators and Circular Business Models}

The themes/topics of sustainable development, environmental sustainability and circular economy also involve cultural heritage with respect to the management models of the same and to the effects/consequences that climate change has on assets $^{31}$; in Italy, one of the most emblematic cases is Venice ${ }^{32}$. These are all

\footnotetext{
${ }^{28}$ Gasca (2020).

${ }^{29}$ Visser is a consultant for the strategic development of community process communication, digital transformation and managerial management of cultural and civic organizations whose activities can be found at the following link https://themuseumofthefuture.com/about/

${ }^{30}$ Videtta (2018).

${ }^{31}$ See UNESCO (2020c) To manage this threat already in 2006, the World Heritage Committee adopted the report "Predicting and Managing the Effects of Climate Change on World Heritage", and a "Strategy to Help States Parties to the Convention Implement Appropriate Management Responses". Also in 2006, the General Assembly of the States Parties to the 1972 Convention adopted a Policy Document on the Impact of Climate Change on World Heritage Sites and strongly recommended its implementation, dissemination and promotion".

${ }^{32}$ Biscontin \& Driussi (2020); Breil (2014); Breil, Gambarelli \& Nunes (2005). Over the years several interventions have been put in place in order to protect the city of Venice and its cultural heritage from the continuous flooding of the Venetian lagoon; the best known/most famous/bigname has been the MOSE system (Modulo Sperimentale Elettromeccanico) that provides mobile barriers to close the lagoon to the sea in case of risk due to exceptional tides. Lastly, in Venezia2021 Programma di ricerca scientifica per una laguna "regolata" /Venezia2021, a scientific research program for a "regulated" lagoon, coordinated by CORILA (Consorzio per il coordinamento delle ricerche inerenti al sistema lagunare di Venezia / Consortium for the coordination of research on the
} 
aspects that have fueled an intense European debate and nurtured various initiatives $^{33}$.

In this scenario multiple resolutions and initiatives are placed such as the Resolution of the Council of the European Union adopted on November 21, 2019 on the cultural dimension of sustainable development and the European projects that followed, such as "CLIC - Circular models Leveraging Investments in Cultural heritage adaptive reuse" funded under the "Horizon 2020" Program ${ }^{34}$. A project launched in December 2017, coordinated by IRISS - Istituto di Ricerca su Innovazione e Servizi per lo Sviluppo of the Consiglio Nazionale delle Ricerche (CNR) joined by 15 partners including research institutions, local government organizations, businesses and local authorities from 10 European Countries which all sees cultural heritage as a «field of experimentation for innovative models of financing, business and governance able to promote and enable the reuse of cultural heritage in European cities and cultural landscapes, in the perspective of circular economy as a model of sustainable development ${ }^{35}$ ».

In a similar manner/Similarly, as emerges from the research, the reuse of heritage from the perspective of regeneration can become a cultural attractor such as to enable the development of circular business models. «If, on the one hand, mass fruition "consumes" the great cultural attractions, on the other hand, most of the existing cultural heritage is far from urban regeneration processes and represents a liability in the development of social and cultural capital. In a logic of circular economy, a transition is developing from a polarised vision (cultural asset to be preserved) to a vision of cultural infrastructure (capital to be enhanced and reproduced). In this vision, the cultural capital is the driver of a regeneration process on an urban or metropolitan scale in which the transverse interconnections between the productive cycles of adaptive reuse of the available heritage, both in the adaptation and in the management phase, configure a circular process of multidimensional production of value ${ }^{36} \gg$.

This vision that is also at the root of European choices and policies, as per the aims and guidelines for 2014-2020 of the Creative Europe Framework Programme (divided into two sub-programmes: Culture and MEDIA), which has put in place a

Venice lagoon system), an association between Ca' Foscari University of Venice, IUAV University of Venice, University of Padua, the National Research Council and the National Institute of Oceanography and Experimental Geophysics, various study and monitoring interventions are planned. In particular in Tematica 5. Cambiamento climatico e strategie di adattamento per la salvaguardia del patrimonio culturale di Venezia e la sua laguna, / Topic 5. Climate change and adaptation strategies for the safeguard of the cultural heritage of Venice and its lagoon, articulated in three specific strands of study, it is expected the development of a series of «procedures for intervention and maintenance of architectural elements and historical materials, which will allow to define and implement a periodic monitoring control of the historical, artistic and cultural heritage present in the lagoon» (see Topic 5 available at the following link http://venezia2021.corila.it/tema tiche/tematica-5/).

${ }^{33} \mathrm{~A}$ key document is ICOMOS, Future of Our Pasts: Engaging Cultural Heritage in Climate Action, edited by ICOMOS and presented in Baku in July 2019 during the $43^{\text {rd }}$ World Heritage Committee.

${ }^{34}$ The project can be found at https://www.clicproject.eu.

${ }^{35}$ Daldanise, Gravagnuolo, Oppido, Ragozino, Cerreta \& Esposito De Vita (2019) at 1352.

${ }^{36}$ Daldanise, Gravagnuolo, Oppido, Ragozino, Cerreta \& Esposito De Vita (2019) at 1349. 
series of actions to support transnational policy cooperation in order to promote innovation, policy development, audience building and new business models for the competitiveness of the sector, with an investment of $€ 1.46$ billion.

\section{Heritage and Culture in the Time of Covid-19: The Impact on Employment}

Heritage and culture are primary economic assets and they must be the core of the National strategy political agenda for the recovery of the Country system and it's the main task of the Institutions to put in place actions and forward-looking investments that, starting from the enhancement and enjoyment of the assets, bring to an economic recovery and employment especially for the younger generations, according to a vision of sustainable well-being with a multi-level approach.

This is the basic assumption on which we develop our thought and a path that can promote sustainable, inclusive and lasting economic growth according to the European vision - also in the light of Agenda 2030, and a full and productive employment and dignified work for all on the assumption that in recent decades the impact of crises and the resulting social disruption have highlighted, on the one hand, critical issues and, on the other, the need to aim at sustainable well-being.

The historical period that we are experiencing due to the Covid-19 pandemic has not spared the world of culture tout court and heritage, which are engines of the economy.

Culture represents a fundamental component of common living and it's considered an essential value of society as well as a daily expression of our citizenship. This strong belief is also reiterated in parliamentary acts and, among them, in the Resolution of the $7^{\text {th }}$ Permanent Commission (Public Education, Cultural Heritage, Scientific Research, Entertainment and Sport) approved on December 13, 2017 (Doc. XXIV no. 89) which, in committing the Government to develop an overall strategy in view of the European Year of Cultural Heritage (2018) - on the assumption that Italy possesses an enormous potential in this sector - highlighted how "Culture, in addition to its social value and intercultural dialogue, is increasingly recognised as a driving economic segment of a strategic nature, especially in our Country, for the development of per capita wealth, welfare and overall national GDP. In Italy, the cultural sector has proven to be one of the sectors with the greatest prospects for growth ${ }^{37}$ ".

UNESCO itself in the survey Impact of Covid-19 on World Heritage Sites and the Tourism Sector ${ }^{38}$ published a map of the consequences of the pandemic in the 167 Countries where there are World Heritage sites and the data shows that «19 States have totally closed their sites (71\%), 17 have left their sites open to the public $(10 \%)$ while $31(19 \%)$ have implemented a partial closure. The impact on local communities is sensitive if we only consider the close link between World Heritage sites and the economy related to cultural tourism». Losses have been estimated around 300-450 billion dollars with a strong negative impact on SME / small and medium-sized businesses.

\footnotetext{
${ }^{37}$ See in Senate document at http://www.senato.it/leg/17/BGT/Testi/Allegati/00000280.pdf ${ }^{38}$ UNESCO (2020a).
} 
UNESCO, in its report Museums around the world in the face of COVID-19 $9^{39}$ pointed out that about $90 \%$ of the world's museums were closed due to the pandemic and that the remaining $10 \%$ may not be able to sustain recovery due to economic difficulties. Similarly, in Europe, according to NEMO (Network of European Museum Organizations) ${ }^{40}$, the daily loss of museum revenues due to the suspension of visits is significant, and must be added to these the charitable contributions and sponsorships for public and private museums. These are all elements that put the financial sustainability of museums at risk, especially smaller ones. This is no different for sites of archaeological interest.

Federculture's XVI Annual Report ${ }^{41}$, in addition to noting the negative impact of Covid-19, highlights the significant reduction in public resources for the cultural sector. From 2000 to 2018, public spending on culture fell by one billion euros, from 6.7 billion in 2000 to 5.7 billion in 2018 .

However, the crisis has shown the Italian criticalities in this, as in other sectors, and has forced shared reflections and a new lymph from the institutions.

In a recent document sent on April 8, 2021 by ISTAT, Esame del disegno di legge n. 2144 (Conversione in legge del decreto-legge 22 marzo 2021, n. 41, recante misure urgenti in materia di sostegno alle imprese e agli operatori economici, di lavoro, salute e servizi territoriali, connesse all'emergenza da COVID-19), it is recorded that the health emergency has led to «a decrease of 187,000 employed in tourism and 33,000 in culture; in percentage terms, this is a drop of $11.3 \%$ and $5.2 \%$ respectively (decidedly higher values than the $-2.0 \%$ recorded on total employment). About half of the employment lost between 2019 and 2020 (-456 thousand people) was in these sectors ${ }^{42}$.

In the X Symbola Report "Io sono Cultura" ${ }^{43}$ ", presented on April 15, 2021, the great impact of the pandemic on the cultural supply chain is evident, due above all to the lockdowns that resulted in the closure of art and culture venues. In detail, the Report also contains a part of analysis on the state of the art of the sector in the pre-pandemic period from which it emerges that if on the one hand in 2019 the core and creative driven segments had produced an added value of about 91 billion euros, with a growth of 1 percent over the previous year, on the other hand the historical and artistic heritage remained at the bottom of the list with its 3 billion euros of added value (See Cosenza 2021). In the overall Italian scenario, this

\footnotetext{
${ }^{39}$ UNESCO (2020b).

${ }^{40}$ Network of European Museum Organizations (NEMO). NEMO was founded in 1992 as an independent network of national museum organizations and it represents the museum community of Council of European member states.

${ }^{41}$ Federculture (2020).

${ }^{42}$ Thus in the document ISTAT, Examination of Bill No. 2144 (Conversion into law of Decree-Law No. 41 of March 22, 2021, on urgent measures in support of businesses and economic operators, labor, health and territorial services, related to the emergency from COVID-19), Commissions 5a (Economic Planning, Budget) and 6a (Finance and Treasury) Senate of the Republic, April 8, 2021.

${ }^{43}$ The Report is promoted by Fondazione Symbola, Fondazione Cariplo, Unioncamere, Regione Marche, Istituto per il Credito Sportivo, with the partnership of Fondazione Fitzcarraldo and Centro Studi delle Camere di Commercio Guglielmo Tagliacarne, under the patronage of the Ministry of Culture, and it can be consulted on the Fondazione Symbola website at the following link https:// www.symbola.net
} 
segment represents 0.2 percent of the total Italian economy and it employs 58,000 people; a figure that should also be read in the light of the positive results of the 2018-2019 period, which saw growth in the sector, with a consequent increase in added value of 2.8 percent, and an increase in employment of 4 percent. Figures, however, lower for heritage than for other sectors such as the creative industries. In broad terms, the report also highlights three critical aspects: the fragmentation among the various cultural subsectors, which implies the need to create a system; the presence of widespread forms of precariousness that often risk translating into undeclared work; the lack of adequate strategic skills in the digital and managerial spheres.

On this basis, it is essential to have a shared strategy among stakeholders to put in place a sort of Marshall Plan of the heritage that has as its reference the values and objectives of the Framework Convention of the Council of Europe on the value of cultural heritage for society (made in Faro on October 27, 2005 and ratified by Italy with October 1, 2020's law, no. 133) in which knowledge and use of heritage are recognised as central elements of the right of citizens to participate in cultural life, as defined in the Universal Declaration of Human Rights, and the role of heritage in the creation of work and employment is reaffirmed.

The encouragement to States is on the one hand to promote a greater synergy of skills among all public, institutional and private actors involved, and on the other to put in place measures that preserve cultural heritage and its sustainable use with the aim of human development and quality of life.

Economy of Culture and Heritage: The Effects on Employment, Employability and Proposals

Given the above, there is a close connection between the economy of culture/heritage and employment, which must be strengthened and enhanced from a systemic perspective.

This combination must be one of the drivers of the post-Covid recovery, recognizing the role of heritage as a strategic lever for development, necessarily linked to the territories and able to feed a production chain based on protection, preservation and enhancement according to innovative business strategies that are also inextricably linked to the tourism sector.

The OECD in the Shock cultura: COVID-19 e settori culturali e creativi, of September 7, 2020, reiterates the need to put in place policies for the recovery and revitalization of local economies that leverage the economic and social impact generated by culture.

As shown by the above-mentioned studies, in fact, there is a real underestimation of cultural employment that most often is not present in the official statistics of the States for various/several reasons. It comes to notice from the cited OECD report, that "when estimating cultural employment, it is difficult to determine what percentage of certain economic activities and professions is truly cultural. For this reason, activities and occupations that are only partially cultural are often excluded from official cultural employment statistics. In addition, labor force surveys include only a respondent's main paid job and do not 
capture the secondary employment or volunteer employment that is present in the $\mathrm{CCS}^{44,}$.

It follows that, in the overall analysis of the workforce of the cultural and creative sectors, an important aspect is the presence of atypical forms of work, more than in other sectors, with the presence of several workers organised in micro enterprises or self-employed professionals, freelancers, for whom there are no public supports such as income support tools in case of economic shocks. A situation that became evident during the pandemic period. Often, in fact, workers employed in these sectors carry out the work activity not in a principal way and they have "combined" contracts with subordinate work contracts, for example part-time, and as such being the activity in question "secondary" with respect to the principal one, which implies that they escape official statistics.

Another specific aspect of jobs in the cultural sector is the presence of specific business models with different governance if we consider that in the sector/branch we go from non-profit realities to public and private institutions such as museums and libraries, to large realities, such as Netflix.

Above all, then, the relationship between tangible and intangible assets, often expression of their intangible nature.

Given these premises, the need emerges to put in place not only systemic actions for the sector and concrete and immediate income support for individual workers (as happened in several Italian regions, in the pandemic period) and companies, including small ones and not only institutions, but especially to design interventions at the legislative level.

It is essential to set up a system of specific policies in order to guarantee social protection, career development and updating of workers' skill in the cultural, heritage and tourism sectors, both to guarantee continuous training (long life learning) and to develop up-to-date models for the certification of skills (see the following paragraph).

The New Professionalism of the Job Market in the Heritage and Culture Sectors: Reference Scenario

Our job market must be able to meet the challenges of a 4.0 economy and it must identify new professional skills and competencies, find out the most of young talents, focus on the transferability and certification of skills acquired in formal and non-formal contexts. All this is possible by providing actions and measures that look carefully and proactively at the «transitional labor markets» ${ }^{45}$ in a job scenario that constantly mutates. But there's more: a side of the doctrine argues that it is scientifically proven that «the sudden obsolescence of technicalprofessional skills, the emergence of new trades and the changing skill profiles

\footnotetext{
${ }^{44}$ Read Note: Adapted from Eurostat, Culture Statistics, Cultural Employment, https://ec.europa.eu/ eurostat/statisticsexplained/index.php/Culture_statistics_-_cultural_employmentb and in $O E C D$, Culture Shock: COVID-19 and the Cultural and Creative Sectors, September 7, 2020. CCS stands for cultural and creative sectors.

${ }^{45}$ Schmid (2011).
} 
needed to control technology confirm the crucial role played by skills development in a modern system of protections» ${ }^{46}$.

We need to implement the Commission's call to «work closely with Cedefop to better estimate and anticipate future skills needs and better match them to job market supply ${ }^{47} \gg$. The cultural employment sector is most affected by this, noting that it is suffering and it needs new blood.

In this scenario, it is necessary to act at the national level (between the institutions in charge) to improve the understanding and comparability of the different qualifications among the various Member States and also to evaluate the proposal to revise and further develop the EQF (European Qualifications Framework $^{48}$ going through cooperation between member states and all stakeholders.

As well as in other sectors ${ }^{49}$ also in culture it is essential to proceed to an analysis of national systems of professional qualifications in order to propose an adaptation of them to meet the changing needs of the new emerging professions also in the direction of the organization, on an annual basis, of a «"European Skills Forum" to allow the relevant authorities, educational institutions, professionals, students, employers and workers to exchange best practices regarding prediction, development and validation of skills ${ }^{50} \gg$.

One of the perspectives could be the realization of a Knowledge and Innovation Community $\left(\mathrm{KICs}^{51}\right.$ ) for cultural heritage and culture, bringing together the main stakeholders from the world of institutions, public authorities, research, organizations that daily strive for the promotion, preservation, protection and enhancement of heritage.

In the renewed scenario that looks towards economic recovery, the younger generations must be educated to understand that heritage can represent an extraordinary entrepreneurial and professional opportunity and that its valorization is equivalent to improving well-being and sociality. A path that also aims to create synergies with the world of education and universities for the activation of targeted courses to train young people with specific professional profiles in the fields of cultural heritage, territorial economy, territorial marketing, art history and tourism.

In this regard, the role of universities is central in order to design courses (undergraduate and postgraduate) that take into account the new needs of the job market in the cultural heritage sector.

\footnotetext{
${ }^{46}$ Casano (2017).

${ }^{47}$ European Parliament (2017).

${ }^{48}$ In the Recommendation of the European Parliament and of the Council on the establishment of a European Qualifications Framework (EQF) for lifelong learning (in Official Journal of the European Union 2008/C 111/01) regarding the establishment of the EQP, Member States are invited «to relate their national qualifications systems to the respective EQF levels and, where appropriate, by developing national qualifications frameworks in accordance with national legislation and practice».

${ }^{49}$ Caragnano \& Danese (2018).

${ }^{50}$ European Parliament (2017) cit. Paragraph 155.

${ }^{51}$ Knowledge and Innovation Communities (KICs), introduced by a European regulation in 2008, are the main operational tool of the European Institute of Technology (EIT), created with the aim of contributing to competitiveness and sustainable economic growth by strengthening the capacities of the EU and its Member States to fully integrate the "knowledge triangle".
} 
In the Research Competencies for Cultural Heritage ${ }^{52}$ of the Foundation School Cultural Heritage Activities - born/originated from the participation of the aforementioned Foundation in the Project Charter Cultural heritage action to refine training, education and roles funded under Erasmus+ and having the aim of defining and building, at European level, a strategy for cultural heritage professions - several interesting aspects emerge such as, on the one hand, the difficulty of measuring the job market in the cultural heritage sector, also due to a difficulty of statistical sources ${ }^{53}$, on the other hand, the lack of a unitary framework of reference of both the occupational and the training capital of the sector. In light of the research, a database was therefore created, among other things, to correlate the professional profiles and roles surveyed with the related activities and training paths.

It follows that it is strategically important to start a process of rebirth able to offer the new generations a renewed and innovative cultural planning and project management skills aimed at the management of new integrated services for culture by promoting wide-ranging actions to create strategies on audience development and /or new cultural business models, improving the skills of cultural operators and national structural policies to compete in the global scenario, also using the great potential of technology.

\section{Conclusion - Final Comments and de iure condendo perspectives}

As anticipated in the opening paragraphs, this essay aims, on the one hand, to promote the study of the research strand of the welfare of the heritage and, on the other, to support and monitor the work of the Assembly of "Gli Stati Generali del Patrimonio Italiano" (The States General of the Italian Heritage), which will take place on May 20, 2021, and which represents a laboratory and an opportunity for reflection and study on the state of the art of our historical, cultural and artistic heritage.

Behind this there is the concept of heritage as an engine of economic development, which also finds its foundation in European policies (as discussed in detail in §4) and which must become the fil rouge of Italian strategic planning.

This is all the more true in an historical moment such as the current one, in which investments for recovery are at the center of the political agenda and of the aforementioned National Recovery and Resilience Plan presented to the European Commission as part of the Next Generation EU (750 billion euro European program for the relaunch of an EU economy overwhelmed by the pandemic crisis), and which sees Italy as the main character in a project of reforms to increase the sustainability of our economy and make it more "resilient" to the changes that are looming in the years of recovery from the Covid crisis.

\footnotetext{
${ }^{52}$ For further discussion read the research, Skills for Cultural Heritage, December 2020, at https:// www.fondazionescuolapatrimonio.it/wp-content/uploads/2021/02/RapportoFinale_Competenze PatrimonioCulturale.pdf

${ }^{53}$ See Bodo, Cabasino, Pintaldi \& Spada (2009); Cabasino (2014); ISFOL (2016).
} 
In 2020 the MiBAC has already started strengthening the specific interventions, such as the Strategic Plan "Major Projects Cultural Heritage" «which aims to boost the competitiveness of the Country with interventions and investments on assets and sites of great interest and national importance for which it is necessary and urgent to implement organic projects of protection, redevelopment, enhancement and cultural promotion, in order to increase the supply and demand for use/cultural fruition ${ }^{54}$,.

This plan, launched step-by-step from August to December 2020, brings together culture and tourism and provides funding of 25 million euros which, added to 103,630,501 euros already allocated (precisely in August 2020) for other projects reach the total value of $128,630,501$ euros.

Other projects have also been launched on the digitalization front and with innovative investments; for example, with Hevolus Innovation (an international company, specialised in research and development of innovative business models for a phygital customer experience) an experimentation, unique in Italy, is being conducted for the fruition of historical and artistic heritage, and from the partnership was also implemented the project of the HoloMuseum of Castel del Monte (in collaboration with Infratel Italia and Microsoft Italia), to enhance culture, the use of digital and in order to offer visitors innovative fruition experiences while expanding the (cultural) offer and relaunching tourism.

Therefore, a broad vision with the basis of work and employment is central and strategic; a vision that points to an innovative management and international scope of heritage to define strategies for the design of structural policies to support and enhance the heritage in a vision "new", detached from the obsolete dynamics and approaches.

In this scenario, "Gli Stati Generali del Patrimonio Italiano" represent an assembly structured in several Commissions (Academies and Universities, Cinema, Economy-Finance-Investments, Europe, Events, Technological Innovation, Work and Employment, Landscape and Territory, Real Estate, Professions, Restoration, Tourism) with the aim of deepening with an consistent, multidisciplinary and transversal approach - and a participatory method - the specificities/details/ peculiarity related to the heritage, in order to reach a systematic cognitive survey of the sector.

Among its various goals, it is particularly interesting because it is in line with the innovative vision mentioned in $\S 3$, to set up an ad hoc fund, Il fondo del patrimonio d'Italia/The Italian Heritage Fund, which could represent an input for the start of a series of actions and investments, including international ones, in the Italian heritage. All this without forgetting the central role of fundraising, patronage and sponsorship in favor of Italian heritage.

The model is a new governance of the heritage that networks and allows the dialogue between the different "souls" of the actors of the cultural heritage, both public and private, but also universities and banking foundations, already actively involved in cultural projects, and that ensures a strategic convergence for an integrated management of the different projects.

\footnotetext{
${ }^{54}$ See MIC, General Secretariat, Strategic Plan for Major Cultural Heritage Projects https://program mazionestrategica.beniculturali.it/piano-strategico-grandi-progetti-beni-culturali/
} 
To cite some examples in this regard, in 2021 only the Cariplo Foundation has allocated 140 million euros for Arts and Culture, also to identify new forms and versions of cultural participation as well as management and demand organization, reaffirming the central role of culture as a «vital element for the social and economic growth of the community, identifying strategic assets necessary for the restart of places and activities: the proximity, for a renewed involvement of the public and creativity for the rethinking of the production and organization of cultural initiatives ${ }^{55}$,"

On the public front, the Cassa Depositi e Prestiti is strategically involved in promoting and supporting projects to valorise Italy's tangible (historical, artistic, archival and real estate) and intangible cultural heritage and its excellence in the world, as well as supporting the spread of the values of the business culture of Italy's industrial history.

The States General of the Italian Heritage/Gli Stati Generali del Patrimonio Italiano (also in the shape of a platform for debate for the network of interdisciplinary experts involved) have a methodological approach that starts from the detailed analysis of the requests of the heritage actors, from the intersection between sectors, supply chains and needs of the territories in order to grasp the specific contribution of each activity to the formation of the added value and of the employment of the sector too.

A shared path between the stakeholders and the "actors" of the system/ apparatus for the search of a new collective identity that is configured as a "Journey of knowledge" based on the exploration of places, social and cultural contexts, the animus of man, who lives in a unique historical period in which it is essential to pool knowledge and culture at a time when we are learning from the present.

A project that aims to initiate a continuous, open and shared confrontation (with many voices) on the topics of interest and lead to the definition of a "Strategic Plan of Italian Heritage" containing proposals for policy, promotion, development and enhancement of Italian heritage, shared and supported by the bodies and organizations operating in the sector, and that can be, at the same time, a participatory proposal to be submitted to the Institutions, primarily the Ministries, responsible for planning, regulating and supporting the heritage sector.

In this context, it is also important to promote and encourage a new and sustainable entrepreneurship of cultural heritage for an economic revitalization that aims to create employment and employability policies, simplyfing and stimulating public-private partnerships and the integration of companies in the sector, while also easing the exchange and transferability of the best practices.

\footnotetext{
${ }^{55}$ Fondazione Symbola (2021).
} 


\section{References}

Amighini, A. (2020). 'Quanto peserà il Covid-19 sull'economia mondiale' in lavoce.info, 13 March.

Antonovsky, A. (1979). Health, stress and coping. San Francisco: Jossey-Bass.

Ascoli, U. \& S. Pasquinelli (1993). Il welfare mix. Stato sociale e terzo settore. Milan: Franco Angeli.

Avanza, G. (2016). 'Protezione e promozione del patrimonio e sviluppo sostenibile' in ASVIS, 13 May.

Bandera, L. (2019). Radicalità e pluralismo, così si genera prosperità inclusiva, in www.secondowelfare.it

Biscontin, G. \& G. Driussi (2020). Gli effetti dell'acqua sui beni culturali valutazioni, critiche e modalità di verifica, Atti del $36^{\circ}$ convegno di studi internazionale Scienza e Beni Culturali, Venezia, 17-19 novembre 2020, Marghera Venezia: Edizioni Arcadia Ricerche.

Bodo, C., Cabasino, E., Pintaldi, F. \& C. Spada (2009). L'occupazione culturale in Italia. Rome: Franco Angeli.

Breil, M., Gambarelli, G. \& P. Nunes (2005). 'Economic Valuation of on-Site Material Damages of High Water on Economic Activities Based in the City of Venice: Results from a Dose-Response-Expert- Based Valuation Approach', in C.A. Fletcher \& T. Spencer (eds). Flooding and Environmental Challenges for Venice and its Lagoon: State of Knowledge. Cambridge, UK: Cambridge University Press.

Bungay, H. \& S. Clift (2010). 'Arts on Prescription: A review of practice in the UK' in Perspect Public Health 130(6):277-81.

Cabasino, E. (2005). I mestieri del Patrimonio. Professioni e mercato del lavoro nei beni culturali in Italia. Rome: Franco Angeli.

Caragnano, R. (2021). 'Investire su welfare comunitario e culturale, in Economia News. Speciale "idee in movimento per una ricostruzione del Paese nell'era del Covid": riflessioni e proposte', in Quotidiano di economia, attualità e politica economica, 18 March.

Caragnano, R. \& G. Danese (2018). Economia del mare: occupazione e prospettive di occupabilità del comparto nautico', in R. Caragnano (a cura di), La Riforma del Codice della Nautica da diporto. Commentario aggiornato al decreto legislativo 3 novembre 2017, n. 229, alla legge delega 7 ottobre 2015, n. 167 e alla legge 27 dicembre 2017 n. 205 (Legge di Bilancio 2018). Tricase: Libellula University Press.

Casano, L. (2017). 'Le transizioni occupazionali nella nuova geografia del lavoro: dieci domande di ricerca' in Nòva La grande trasformazione del lavoro, 23 February, Il Sole 24 ore e ADAPT.

Cavalli, N. (2016). La biblioteca come luogo terzo volano di creatività, in Biblioteche sostenibili creatività, inclusione, innovazione, Atti del 59 congresso nazionale dell'Associazione italiana biblioteche Roma, November, pp. 17-24.

Cicerchia A., Rossi Ghiglione, A. \& C. Seia (2020). 'Welfare culturale' in "Atlante", Treccani.

Costa, G. (2009). Prove di welfare locale. La costruzione di livelli essenziali di assistenza in provincia di Cremona. Milan: Franco Angeli.

Daldanise, G., Gravagnuolo, A., Oppido, S., Ragozino, S., Cerreta, M. \& G. Esposito De Vita (2019). 'Economie circolari per il patrimonio culturale: processi sinergici di riuso adattivo per la rigenerazione urbana' Atti della XXI Conferenza Nazionale SIU | CONFINI, MOVIMENTI, LUOGHI. Politiche e progetti per città e territori in transizione, pp. 1348-1361. 
European Parliament (2017). A new skills agenda for Europe. European Parliament resolution of 14 September 2017 on a new skills agenda for Europe (2017/2002(INI)).

Fan V.Y, Jamison, D.T. \& L.H. Summers (2018). 'Pandemic risk: how large are the expected losses?' in Bull World Health Organization 96:129-134.

Federculture (2020) Impresa Cultura Dal tempo della cura a quello del rilancio, XVI Rapporto Annuale Federculture. Rome: Gangemi Editore.

Fondazione Symbola (2021) Io sono Cultura 2021, L'Italia della qualità e della bellezza sfida la crisi. https://www.symbola.net/ricerca/io-sono-cultura-2021

Gasca, E. (2020). 'Culture 2030 Indicators - la cultura per l'agenda dello sviluppo sostenibile' in Ag Cult, 8 June.

GPMB (2019). 'A World at Risk'. Annual report on global preparedness for health emergencies. Global Preparedness Monitoring Board, http://apps.who.int.

Grossi, E. \& A. Ravagnan (2013), Cultura e salute. La partecipazione culturale come strumento per un nuovo welfare, Milano: Springer-Verlag.

ICOMOS (2019). Future of Our Pasts: Engaging Cultural Heritage in Climate Action.

ISFOL, Ares 02 (2016), Scenari: Anticipazione dei fabbisogni professionali per il settore dei beni culturali, https://ares20.it/

ISTAT (2021b), Esame del disegno di legge n. 2144 (Conversione in legge del decretolegge 22 marzo 2021, n. 41, recante misure urgenti in materia di sostegno alle imprese e agli operatori economici, di lavoro, salute e servizi territoriali, connesse all'emergenza da COVID-19), Commissioni 5a (Programmazione economica, bilancio) e 6a (Finanze e tesoro) Senato della Repubblica, 8 aprile.

Lindström, B. \& M. Eriksson (2005). 'Salutogenesis' in Journal of Epidemiol Community Health 59:440-442.

Maino, F. (2015). 'Secondo welfare e territorio: risorse, prestazioni, attori, reti,' in F. Maino \& M. Ferrera (eds.) Secondo Rapporto sul secondo welfare in Italia 2015. Torino: Centro di Ricerca e Documentazione Luigi Einaudi.

Maino, F. \& M. Ferrera (2019). 'Nuove alleanze per un welfare che cambia' in Quarto Rapporto sul secondo welfare in Italia, Percorsi di Secondo Welfare. Torino: Giappichelli Editore.

Mannino, F. (2016). 'Appunti di viaggio. Verso una definizione di welfare culturale', in $I l$ Giornale delle Fondazioni. Venice: Fondazione Venezia 2000.

Mental Health Foundation (2009). New Data Shows Overreliance on Antidepressants, says Mental Health Foundation. London: Mental Health Foundation.

Montalto, V. (2021). Cultura per lo sviluppo sostenibile: misurare l'immisurabile? In www.fondazioneunipolis.org

Novy, L. (2018), Il cuore pulsante di una biblioteca è la persona, Goethe-Institut,

OECD (2020). 'Shock cultura: COVID-19 e settori culturali e creativi' in www.oecdilibrary.org

OMS (2019). 'What is the evidence on the role of the arts in improving health and wellbeing?' in www.euro.who.int

ONU (2005). Transforming our world: the 2030 Agenda for Sustainable Developmen.

Presidenza del Consiglio dei Ministri (2021), Piano Nazionale di Ripresa e Resilienza. \#NEXTGENERATIOITALIA. Italia Domani.

Sacco, P.L. (2017). 'Appunti per una definizione di welfare culturale' in "Il Giornale delle Fondazioni”, Venezia, Fondazione Venezia 2000.

Schmid, G. (2011). 'Il lavoro non standard. Riflessioni nell'ottica dei mercati transizionali del lavoro' in Diritto delle Relazioni Industriali, 1:1-36. 
Stiglitz, J., Sen, A. \& J. Fitoussi (2009). Report by the Commission on the Measurement of Economic Performance and Social Progress, https://ec.europa.eu

UNESCO (2009), The 2009 UNESCO framework for cultural statistics (FCS).

UNESCO (2014), Culture for development indicators.

UNESCO (2019), "Culture 2030 Indicators" (CI), http://www.unesco.it

UNESCO (2020a). Documento di policy sull'impatto dei cambiamenti climatici sui siti del patrimonio mondiale Unesco. http://www.unesco.it/it/News/Detail/756

UNESCO (2020b), Impatto del Covid-19 sui siti del patrimonio mondiale e sul settore del turismo. https://unesdoc.unesco.org/ark:/48223/pf0000373530.

UNESCO (2020c), Policy Document on the Impact of Climate Change on UNESCO World Heritage Sites. http://www.unesco.it/it/TemiInEvidenza/Detail/43

Videtta, C. (2018). Cultura e sviluppo sostenibile. Alla ricerca del IV pilastro, Torino, Giappichelli. 
